FOLIA POMERANAE UNIVERSITATIS TECHNOLOGIAE STETINENSIS

Folia Pomer. Univ. Technol. Stetin., Oeconomica 2018, 342(90)1, 37-46

Jolanta KONDRATOWICZ-POZORSKA

\title{
DOCHODY ROLNIKÓW A ROZWÓJ USŁUG NA TERENACH WIEJSKICH
}

\section{INFLUENCE OF FARMERS' INCOMES ON DEVELOPMENT OF SERVICES IN RURAL AREAS}

Zakład Rachunkowości, Politechnika Koszalińska

ul. Eugeniusza Kwiatkowskiego 6e, 75-343 Koszalin

\begin{abstract}
Summary. At study, it was tried to check whether Polish farmers have adequate incomes and own capital, which allows on the one hand the creation of new non-agricultural jobs, and secondly: it enables the use of services offered by other entities located in rural areas. Achieving the goal of work in 2017 was also carried out a questionnaire in two communes in Western Pomerania. The questionnaire results were done to help determine which services are most often used by farmers and what part of the budget they spend on services provided in rural areas.
\end{abstract}

Słowa kluczowe: dochody rolników, rozwój usług, tereny wiejskie, wydatki na usługi.

Key words: farmers' income, development of services, rural areas, financial expenses for services.

\section{WSTĘP}

Już pod koniec lat 90. XX wieku zwracano uwagę, iż do podstawowych barier wielofunkcyjnego rozwoju obszarów wiejskich (WROW) w Polsce, oprócz bariery instytucjonalnej, infrastrukturalnej, małej aktywności ludności wsi, zalicza się także (Woś 1998):

- barierę popytu na dobra i usługi oferowane przez powstające przedsiębiorstwa, wynikającą z niskich dochodów ludności wiejskiej; powoduje ona, że perspektywy rozwojowe wykazują przede wszystkim przedsiębiorstwa ukierunkowane na zaspokajanie popytu ponadlokalnego;

- barierę kapitałową polegającą na ograniczonych możliwościach finansowania rozwoju przedsiębiorczości na podstawie kapitału własnego i niewielkiej dostępności środków ze źródeł zewnętrznych.

Powstało wiele prac naukowych i opracowań empirycznych dotyczących tego, jak rozumieć WROW oraz jak i w jaki sposób do codziennej rzeczywistości gospodarczej wdrażać określone działania, by WROW umiejętnie wkomponował się w przestrzeń polskiej wsi i wygenerował większą liczbę nowych funkcji pozarolniczych. Autorzy prac z zakresu nauk ekonomiczno-rolniczych założyli potrzebę kreowania pozarolniczych rodzajów działalności gospodarczej i nowych miejsc pracy, by wymusić procesy modernizacyjne rolnictwa i sprawić, by obszary wiejskie podlegały przekształceniom w kierunku wielofunkcyjności (np. Kłodziński 2002; Spychalski 2004). Adamowicz i Zwolińska-Ligaj (2009) również odnoszą się do potrzeby tworzenia na obszarach wiejskich nowych miejsc pracy, czego konsekwencją będą nowe 
źródła dochodów mieszkańców wsi oraz zwiększanie atrakcyjności wsi jako miejsca pracy i zamieszkania. Obecnie po upływie prawie 25 lat od zaprezentowania koncepcji zrównoważonego rozwoju obszarów wiejskich w Polsce jej realizacja jest, niestety, niesatysfakcjonująca.

Wobec powyższego, bazując na poglądach Wosia (1998), należałoby sprawdzić, czy polscy rolnicy i mieszkańcy wsi dysponują odpowiednim dochodem i kapitałem własnym, który pozwala, z jednej strony, na tworzenie nowych pozarolniczych miejsc pracy, a z drugiej strony umożliwia korzystanie $z$ usług oferowanych przez inne podmioty zlokalizowane na terenach wiejskich. W tym celu w 2017 roku przeprowadzono badania ankietowe w województwie zachodniopomorskim, które miały na celu określenie, z jakich usług rolnicy najczęściej korzystają i jaką część budżetu przeznaczają na usługi świadczone na terenach wiejskich.

\section{MATERIA I METODY}

$\mathrm{Na}$ potrzeby realizacji tematu konieczne było przeprowadzenie studiów literaturowych z zakresu uwarunkowań wielofunkcyjnego rozwoju obszarów wiejskich w Polsce, a także rozwoju usług na obszarach wiejskich. Ponadto zebrano i przeanalizowano materiał teoretyczny i wiele empirycznych opracowań specjalistycznych takich instytucji, jak: IRWiR PAN, Komisja Europejska oraz GUS, w których zaprezentowano dochody ludności wiejskiej, a szczególnie dochody osób utrzymujących się z rolnictwa.

Jednocześnie, realizując cel pracy, w 2017 roku przeprowadzono badania ankietowe w dwóch zachodniopomorskich gminach wiejskich. Pierwsza z nich to gmina Kobylanka leżąca pomiędzy Szczecinem a Stargardem, druga natomiast to typowa gmina wiejska oddalona od dużych i średnich miast - Karnice. Wybór uzasadniony był tym, że gminy te pod względem liczby ludności i powierzchni są prawie identyczne; różni je położenie względem dużych i średnich miast. Gmina Kobylanka leży w zachodniej części województwa zachodniopomorskiego; od Stargardu dzieli ją $11 \mathrm{~km}$, od Szczecina - 24 km. Gmina Karnice leży w północno-zachodniej części województwa, z dala od dużych aglomeracji miejskich. Najbliższe miasta to Kołobrzeg, oddalony o ok. 50 km, i Goleniów - o 78 km. Odległość gminy od Szczecina wynosi ok. $111 \mathrm{~km}$, od Stargardu - ponad 115. Charakterystykę obu gmin na podstawie wybranych parametrów społeczno-ekonomicznych przedstawiono w dalszej części opracowania.

Ankieta skierowana była do rolników z dwóch wybranych gmin. Mimo że pytania były wysłane do wszystkich właścicieli gospodarstw rolnych w gminach Kobylanka i Karnice, do analizy zostały zaakceptowane tylko te dokumenty, które spełniały wszystkie wymagania formalne. Ostatecznie do badania zatwierdzono 48 formularzy z gminy Kobylanka i 76 z Karnic. Kwestionariusz zawierał 4 pytania zamknięte i 4 pytania otwarte.

\section{DOCHODY ROLNIKÓW W LATACH 2004-2016}

Według danych publikowanych przez GUS pod koniec 2016 roku w Polsce funkcjonowało około1,4 mln gospodarstw rolnych. GUS corocznie oblicza także dochody z hektara przeliczeniowego; dane te są podstawą otrzymania pomocy społecznej, ubiegania się 
o stypendium socjalne przez studentów - dzieci rolników, również do obliczenia, czy rodzinie rolnika przysługuje wsparcie z programu 500+ także na pierwsze dziecko. Natomiast korzystając z danych gromadzonych przez Komisję Europejską, można było dowiedzieć się, jaki jest przychód roczny w rodzinnych gospodarstw rolnych. Szczegółowe dane zawarto w tab. 1.

Tabela 1. Dane dotyczące dochodów polskich rolników w latach 2004-2016

\begin{tabular}{|l|c|c|c|c|}
\hline Lata & $\begin{array}{c}\text { Dochody z 1 ha } \\
\text { przeliczeniowego } \\
\text { [zł/mies.] }\end{array}$ & $\begin{array}{c}\text { Roczny przychód } \\
\text { z rodzinnego } \\
\text { gospodarstwa } \\
\text { rolnego [EUR] }\end{array}$ & $\begin{array}{c}\text { Dynamika zmian } \\
\text { dochodów z 1 ha } \\
\text { przeliczeniowego } \\
{[\%]}\end{array}$ & $\begin{array}{c}\text { Dynamika zmian przychodów } \\
\text { z rodzinnego gospodarstwa } \\
\text { rolnego } \\
\text { [\%] }\end{array}$ \\
\hline 2016 & 2577 & 5319 & 1,30 & 0,98 \\
\hline 2015 & 1975 & 5427 & 0,79 & 0,93 \\
\hline 2014 & 2506 & 5805 & 0,87 & 0,89 \\
\hline 2013 & 2869 & 6511 & 1,23 & 0,94 \\
\hline 2012 & 2341 & 6931 & 0,86 & 1,07 \\
\hline 2011 & 2713 & 6977 & 1,19 & 1,53 \\
\hline 2010 & 2278 & 6530 & 1,19 & 0,80 \\
\hline 2009 & 1908 & 4279 & 0,93 & 0,83 \\
\hline 2008 & 2056 & 5345 & 0,93 & 1,34 \\
\hline 2007 & 2220 & 6415 & 1,17 & 1,29 \\
\hline 2006 & 1898 & 4800 & 1,03 & 0,95 \\
\hline 2005 & 1844 & 3731 & 1,13 & - \\
\hline 2004 & 1626 & 3930 & - & \\
\hline
\end{tabular}

Źródło: opracowano na podstawie danych GUS i danych z rachunkowości rolnej gromadzonych przez Komisję Europejską Departament Rolnictwa i Rozwoju Obszarów Wiejskich (FADN Public Database, http://ec.europa.eu/agriculture/rica/database/report_en.cfm?dwh=SO).

Z analizy danych zaprezentowanych w tab. 1 wynika, że dochody z 1 ha przeliczeniowego były korzystne dla polskich rolników w czterech okresach, tj. w latach 2004-2007 i 2010-2011 oraz w roku 2013 (kiedy zanotowano największą ich wartość) i w roku 2016. Jednakże biorąc pod uwage przychody w rodzinnych gospodarstwach rolnych, można stwierdzić, że w tym wypadku jest zdecydowanie gorzej. Tylko w latach 2006-2007 i 2010-2011 (najwyższe odnotowane przychody) można mówić o wzrastających przychodach (liczonych rok do roku). Niestety, zarówno analiza danych dotyczących poziomu dochodów miesięcznych, jak i rocznych przychodów - mimo iż wskazuje na poprawę sytuacji mieszkańców wsi - potwierdza, że koniunktura dochodowa jest bardzo zmienna i nieprzewidywalna. Obraz warunków dochodowych polskich rolników staje się jeszcze mniej korzystny, gdy porówna się ich dochody z danymi dla całej Polski. Na przykład w 2015 roku średni dochód Polaka wynosił $4067 \mathrm{zł} /$ mies., podczas gdy rolnik prowadzący około 10-hektarowe gospodarstwo zarabiał w granicach 65\% średniej krajowej, czyli 2651 zł brutto (Rocznik Statystyczny Województwa Zachodniopomorskiego 2016). Podobne wyliczenia podaje serwis: moja-pensja.pl, z których wynika, że przeciętny miesięczny zarobek rolnika w tym roku wynosił ok. 2,9 tys. zł brutto (Ile zarabia polski rolnik? http://superbiz.se.pl/wiadomosci-biz/ile-zarabia-polski-rolnik-prawda-o-pieniadzach-na-wsi_593362.html). A zatem dochody polskich rolników, mimo znacznego wsparcia finansowego ze środków w ramach wspólnej polityki rolnej UE (udział wsparcia w ogólnych dochodach rolników sięga ok. 40\%), były i nadal są niewysokie. Jeszcze gorzej dla rolników sytuacja wygląda, gdy porówna się dochód rozporządzalny na jedną osobę, 
wyliczony w 2016 roku. W przypadku całej Polski wynosi on ok. 1426 zł/os., natomiast w indywidualnych gospodarstwach rolnych utrzymujących się z rolnictwa - tylko ok. 393 zł/os. (Rocznik Statystyczny Polski 2017).

\section{WYNIKI BADAŃ ANKIETOWYCH}

W związku z tym, że nie ma opracowań wiążących wysokość dochodów rolników z wydatkami na poszczególne rodzaje usług przeprowadzono samodzielne badania ankietowe. Uzyskane wyniki miały przyczynić się do poznania następujących kwestii:

- z jakich rodzajów usług rolnicy najczęściej korzystają;

- jakie rodzaje usług, z których korzystają rolnicy, powinny być zlokalizowane na terenach wiejskich;

- jaki procent dochodu miesięcznego rolnicy wydają na korzystanie z usług.

Badania przeprowadzono w roku 2017 na terenie województwa zachodniopomorskiego w gminach wiejskich Kobylanka i Karnice. Podmioty objęte badaniem to gospodarstwa domowe utrzymujące się wyłącznie $z$ pracy na roli. Wybór gospodarstw rolnych $w$ tych konkretnych gminach województwa zachodniopomorskiego nie był przypadkowy - jest to dawny region popegeerowski, w którym aż 99\% wszystkich gospodarstw rolnych należy obecnie do sektora prywatnego. Szczegółową charakterystykę wymienionych gmin przedstawiono $w$ tab. 2 .

Tabela 2. Charakterystyka gmin Kobylanka i Karnice pod względem społeczno-gospodarczym (stan na koniec grudnia 2016 r.)

\begin{tabular}{|l|c|c|}
\hline \multicolumn{1}{|c|}{ Cechy } & \multicolumn{2}{c|}{ Gmina } \\
\cline { 2 - 3 } \multicolumn{1}{|c|}{} & Kobylanka & Karnice \\
\hline Powierzchnia [km²] & 122 & 133 \\
\hline Ludność [tys. os.] & 5,3 & 4,1 \\
\hline Gęstość [os./km²] & 44 & 32 \\
\hline Dochody budżetu gminy [mln zł] & 4365 & 3891 \\
\hline Wydatki budżetu gminy [mln zł] & 4278 & 3811 \\
\hline Dochód na 1 mieszkańca [zł] & 4365 & 3891 \\
\hline Pracujący na 1000 mieszkańców & 157 & 53 \\
\hline Bezrobotni & 140 & 283 \\
\hline $\begin{array}{l}\text { Podmioty gospodarki narodowej w REGON na 10 tys. mieszkańców w wieku } \\
\text { produkcyjnym }\end{array}$ & 2213 & 1515 \\
\hline Liczba gospodarstw rolnych objętych badaniem & 48 & 76 \\
\hline
\end{tabular}

Źródło: obliczono na podstawie: Statystyczne vademecum samorządowca 2017. Kobylanka, http://szczecin.stat.gov.pl/ /vademecum/vademecum_zachodniopomorskie/portrety_gmin/powiat_stargardzki/gmina_wiejska_kobylanka.pdf; Statystyczne vademecum samorządowca 2017. Karnice, http://szczecin.stat.gov.pl/vademecum/vademecum_ zachodniopomorskie/portrety_gmin/powiat_stargardzki/gmina_wiejska_karnice.pdf oraz Bazy Danych Lokalnych, https://bdl.stat.gov.pl/BDL/start.

Każdy kwestionariusz zawierał 8 pytań i metryczkę. Na tej podstawie scharakteryzowano grupy rolników biorących udział w badaniu i zapoznano się z ich opiniami nt. korzystania z poszczególnych usług. Wyniki analizy przedstawiono w tabelach i na poszczególnych wykresach zaprezentowanych poniżej. Rycina 1 ukazuje rozkład dochodów rozporządzalnych na 1 osobę w badanych gospodarstwach. 
2

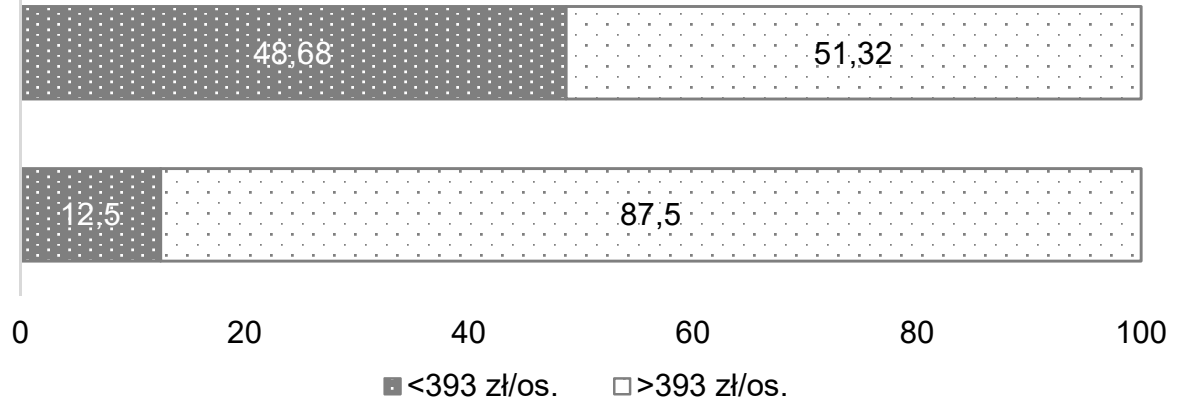

Ryc. 1. Struktura badanych gospodarstw pod względem wysokości dochodu rozporządzalnego na jedną osobę gmin Kobylanka (1) i Karnice (2) [\%]. Numerem 1 oznaczono gminę Kobylanka (I grupa badawcza), numerem 2 - gminę Karnice (II grupa badawcza)

Zdecydowana większość rolników zamieszkujących gminę Kobylanka dysponuje wyższym dochodem aniżeli średni dochód rozporządzalny wyliczony dla gospodarstw rolnych w Polsce. Natomiast w gminie Karnice rozkład jest prawie symetryczny, tzn. ok. 49\% ankietowanych miało dochód niższy niż 393 zł/os., a 51\% wyższy od kwoty 393 zł/os. Można zatem stwierdzić, że rolnicy w I grupie badawczej dysponują większą siłą nabywczą aniżeli rolnicy z II grypy. W związku z tym sprawdzono, czy w gminie Kobylanka rolnicy częściej korzystają z usług, a gdyby takie usługi były dostępne na wsi, czy chcieliby z nich w przyszłości skorzystać. Suma wyników nie daje wartości 100\%, bowiem ankietowani mogli zaznaczyć tyle rodzajów usług, z ilu rzeczywiście korzystają. W tabeli 3 przedstawiono rozkład odpowiedzi na pierwsze dwa pytania: 1. Z jakich usług korzystacie Państwo na co dzień? 2. Z jakich rodzajów usług chcieliby Państwo chętniej korzystać w przyszłości, gdyby były dostępne na wsi? Były to tzw. pytania zamknięte.

Bez względu na rodzaj grupy badawczej i przyjęte kryteria ankietowani z więcej niż co drugiego gospodarstwa zaznaczyli, że korzystali z usług edukacyjnych, komunalnych oraz ochrony zdrowia i opieki społecznej. Z kolei ankietowani o dochodach powyżej 393 zł/os. (zarówno z I, jak i II grupy) zaznaczyli dodatkowo, że korzystali z handlu i usług. W Kobylance zamożniejsza grupa badanych zaznaczyła również transport i łączność oraz usługi informatyczne i pokrewne. Jednak niewielu ankietowanych chce w przyszłości korzystać z usług, nawet wówczas, gdyby były dostępne na terenach wiejskich. Wyniki są o tyle zaskakujące, że z usług (np. z handlu i napraw, hoteli i restauracji, edukacji, ochrony zdrowia i in., rekreacji, kultury i sportu, wynajmu maszyn) chętniej korzystaliby mieszkańcy Karnic niż Kobylanki. Tylko w przypadku usług związanych z rekreacją, kulturą i ze sportem co trzeci badany z Kobylanki o dochodach powyżej 393 zł/os zaznaczył, że częściej korzystałby z tego rodzaju usług, gdyby były one dostępne na terenach wiejskich.

Pytanie 3 miało na celu sprawdzenie, czy ludność związana dotychczas z rolnictwem chciałaby poprowadzić jakąkolwiek działalność usługową. Na to pytanie w Kobylance $28 \%$ ankietowanych odpowiedziało twierdząco, w tym $10 \%$ z nich osiągało dochód poniżej średniego dochodu rozporządzalnego na 1 osobę w gospodarstwach indywidualnych. W gminie Karnice zaś tylko ok. 10\% badanych, tj. 8 podmiotów, zaznaczyło: tak. Dwie odpowiedzi były od osób mniej zamożnych, a 6 od osób z dochodem powyżej 393 zł/os. 
Jednak na kolejne pytanie: Czy usługi mają szansę rozwijać się na terenach wiejskich? tylko 5 ankietowanych z Kobylanki i 3 z Karnic udzieliło optymistycznej odpowiedzi. Rolnicy nie widzą perspektyw rozwoju innych form działalności i związanych z nimi miejsc pracy na terenach wiejskich. Zaskakujące jest to, że wśród odpowiedzi na ww. pytanie wszyscy, którzy chcieliby świadczyć usługi, chcą to robić, korzystając przede wszystkim z własnego kapitału (80\% odpowiedzi; $20 \%$ zaciągnie dodatkowo kredyt na rozwój działalności usługowej).

Kolejne pytania miały charakter pytań otwartych. Miały one pomóc wyjaśnić, dlaczego mimo poprawiającej się sytuacji materialnej rolników (od wejścia Polski do UE) - na terenach wiejskich nadal nie zachodzą szybkie i korzystne zmiany w strukturze zatrudnienia.

Tabela 3. Rozkład odpowiedzi na pytania dotyczące usług (pytania 1 i 2)

\begin{tabular}{|c|c|c|c|c|c|c|c|c|}
\hline \multirow{3}{*}{ Rodzaje usług } & \multicolumn{4}{|c|}{$\begin{array}{l}\text { Z jakich usług korzystają Państwo } \\
\text { na co dzień? }\end{array}$} & \multicolumn{4}{|c|}{$\begin{array}{l}\text { Z jakich rodzajów usług chcieliby Państwo } \\
\text { chętniej korzystać w przyszłości? }\end{array}$} \\
\hline & \multicolumn{2}{|c|}{ Kobylanka } & \multicolumn{2}{|c|}{ Karnice } & \multicolumn{2}{|c|}{ Kobylanka } & \multicolumn{2}{|c|}{ Karnice } \\
\hline & $<393$ zł/os. & $>393 \mathrm{zł} / \mathrm{os}$. & <393 zł/os. & $>393 \mathrm{zł} / \mathrm{os}$ & $<393 \mathrm{zł} / \mathrm{os}$ & $393 \mathrm{zł/os}$. & $<393 \mathrm{z}$ /os. & $393 \mathrm{zł} / \mathrm{os}$. \\
\hline Handel i naprawy & 10 & 60 & 5 & 55 & 10 & 20 & 30 & 30 \\
\hline Hotele i restauracje & 0 & 10 & 0 & 5 & & 10 & 5 & 10 \\
\hline $\begin{array}{l}\text { Transport } \\
\text { i łączność }\end{array}$ & 20 & 60 & & & 5 & 10 & 10 & 10 \\
\hline Usługi osobiste & 0 & 5 & 0 & 0 & & & & \\
\hline $\begin{array}{l}\text { Działalność } \\
\text { komunalna }\end{array}$ & 90 & 100 & 60 & 90 & & & & \\
\hline Edukacja & 60 & 90 & 50 & 80 & 10 & 20 & 20 & 20 \\
\hline $\begin{array}{l}\text { Ochrona zdrowia } \\
\text { i opieka społeczna }\end{array}$ & 100 & 100 & 100 & 100 & 20 & 20 & 30 & 25 \\
\hline $\begin{array}{l}\text { Rekreacja, kultura, } \\
\text { sport }\end{array}$ & 10 & 45 & 10 & 20 & 10 & 30 & 10 & 20 \\
\hline $\begin{array}{l}\text { Transport } \\
\text { i gospodarka } \\
\text { magazynowa }\end{array}$ & 5 & 20 & 5 & 20 & & & & \\
\hline $\begin{array}{l}\text { Pośrednictwo } \\
\text { finansowe } \\
\text { i nieruchomości }\end{array}$ & 0 & 10 & 0 & 5 & & & & \\
\hline $\begin{array}{l}\text { Wynajem maszyn } \\
\text { i sprzętu }\end{array}$ & 0 & 25 & 5 & 20 & 5 & 10 & & 20 \\
\hline $\begin{array}{l}\text { Informatyka } \\
\text { i pokrewne }\end{array}$ & 10 & 80 & 20 & 40 & & & & \\
\hline $\begin{array}{l}\text { Prace badawczo- } \\
\text {-rozwojowe }\end{array}$ & 0 & 0 & 0 & 0 & & & & \\
\hline $\begin{array}{l}\text { Inne związane } \\
\text { z biznesem }\end{array}$ & 0 & 5 & 0 & 0 & & & & \\
\hline $\begin{array}{l}\text { Administracja } \\
\text { publiczna i obrona } \\
\text { narodowa }\end{array}$ & 0 & 0 & 0 & 0 & & & & \\
\hline $\begin{array}{l}\text { Działania } \\
\text { organizacji } \\
\text { członkowskich }\end{array}$ & 2 & 15 & 5 & 5 & & & & \\
\hline $\begin{array}{l}\text { Organizacje } \\
\text { i zespoły narodowe }\end{array}$ & 0 & 10 & 0 & 0 & & & & \\
\hline
\end{tabular}

Ludność rolnicza wskazała, że do najważniejszych powodów niekorzystania z usług należy brak środków finansowych i niewysoka jakość świadczonych usług; dopiero po nich wskazano na brak czasu. Szczegółowy rozkład odpowiedzi przedstawia ryc. 2. 


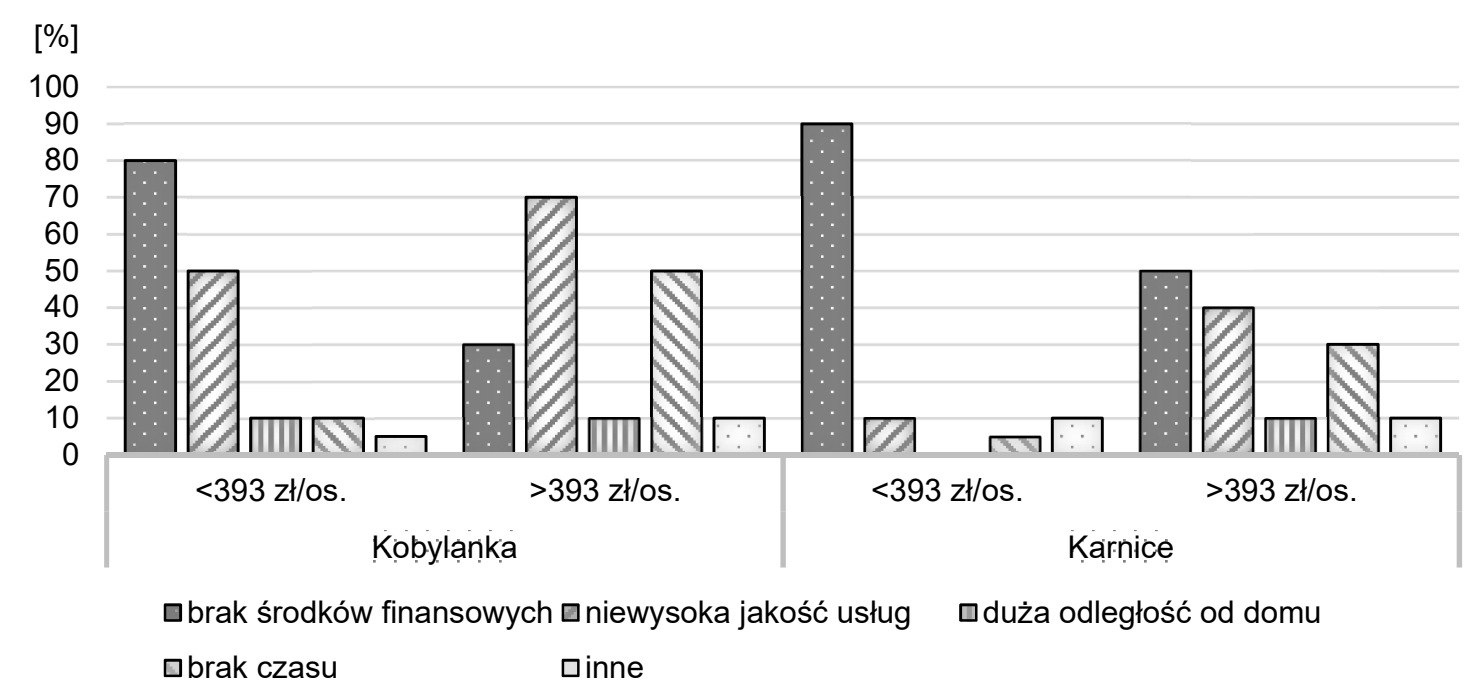

Ryc. 2. Rozkład najczęściej udzielonych odpowiedzi na pytanie 4 o powody, dla których ludność wiejska nie korzysta z usług

Pytanie 5 dotyczyło rodzajów usług, które powinny być świadczone na wsi lub w najbliższej okolicy. Odpowiedzi były prawie jednakowe w dwóch grupach badawczych. W gminie Kobylanka $70 \%$ respondentów stwierdziło, że nie widzi perspektyw rozwoju wskazanych usług w swoim miejscu zamieszkania. W gminie Karnice podobnych odpowiedzi było $60 \%$. Z odpowiedzi wynika, że w gminie Kobylanka mieszkańcy korzystają głównie z usług świadczonych w pobliskich miastach, w Karnicach te usługi, które są dostępne, są wystarczające.

Na pytanie 6 o usługi, które powinny być rozwijane w najbliższym sąsiedztwie, odpowiedzi były sporadyczne. Jeżeli już wymieniono usługi, które powinny charakteryzować się większą dynamiką rozwoju, to były to głównie: usługi kulturalne, rekreacyjne i sportowe oraz transport i agroturystyka. W związku z uzyskanym materiałem empirycznym można stwierdzić, że badani oczekują rozwoju usług na terenach wiejskich, ale nie widzą takich możliwości w swojej wsi lub w najbliższej okolicy.

Kolejne pytanie (pyt. 7) dotyczyło wysokości wydatków, jakie są przeznaczane miesięcznie z budżetu domowego rolników na różnego rodzaju usługi. Pytano ponadto, czy rolnicy są gotowi wydawać więcej pieniędzy na usługi (pyt. 8). Rycina 3 przedstawia rozkład uzyskanych odpowiedzi.

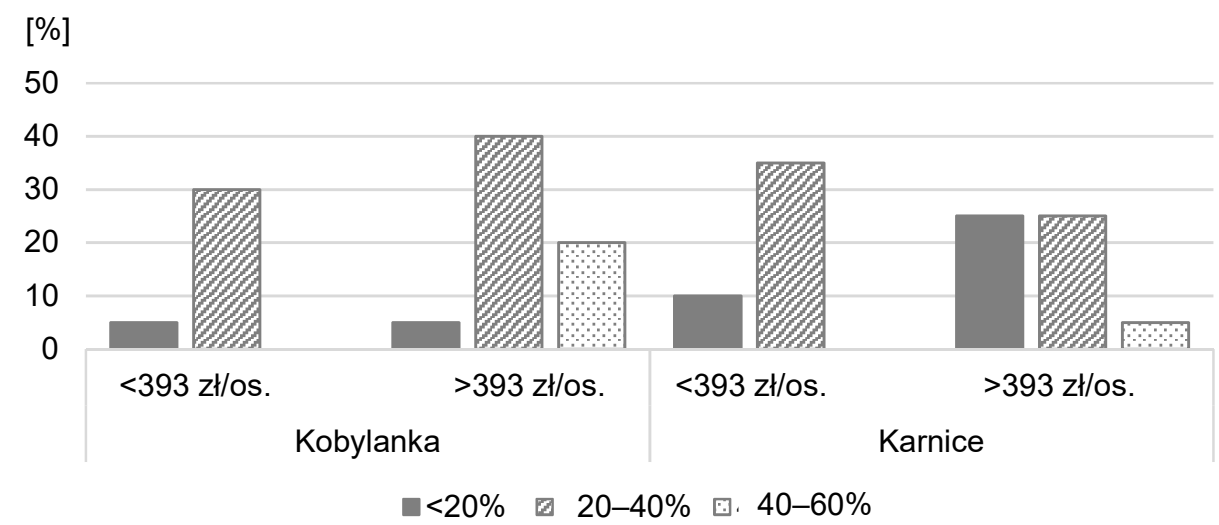

Ryc. 3. Udział wydatków na usługi w ogólnych dochodach ankietowanych rolników 
Rolnicy z gmin Kobylanka i Karnice o dochodach wyższych, niż średni dochód rozporządzalny, stanowią grupę, w której dominują osoby wydające na usługi 20-40\% swoich dochodów. Jednak są i tacy, szczególnie w gminie Kobylanka, w przypadku których udział wydatków na usługi w budżecie domowym sięga nawet $60 \%$.

W czterech grupach badawczych aż $90 \%$ ankietowanych nie jest skłonnych wydawać więcej środków finansowych, lecz oczekuje przede wszystkim działań i czynności towarzyszących usługom bezpłatnym.

\section{PODSUMOWANIE}

W 2016 roku pracujący w rolnictwie, leśnictwie, łowiectwie i rybołówstwie stanowili tylko $9,6 \%$ pracujących. Niechęć do podjęcia pracy w tych działach gospodarki jest spowodowana przede wszystkim: a) dużą zależnością efektów pracy od czynników nieprzewidywalnych, np. warunków pogodowych; b) niskim wynagrodzeniem za pracę. W związku z tym na terenach wiejskich notuje się coraz mniej osób, które utrzymują się tylko z pracy w gospodarstwie rolnym. Dochody rolników z lat 2004-2016, przedstawione w pracy w różnych ujęciach, potwierdzają, że rolnicy nie mają dobrej sytuacji finansowej. Można stwierdzić, że jest ona lepsza tylko w przypadku rencistów i emerytów. Prowadzone badania ankietowe wykazały, że średni dochód rozporządzalny, publikowany przez GUS, jest miarodajny w gminie typowo rolniczej, w której nie ma dominujących ośrodków miejskich (np. w gminie Karnice). Natomiast w gminach o bardzo korzystnym położeniu, tj. w bliskim sąsiedztwie dużych miast, więcej rolników osiąga dochody powyżej średniego dochodu rozporządzalnego. Jednak takich gmin wiejskich w Polsce jest stosunkowo niewiele. A zatem bariera popytowa na polskiej wsi nadal istnieje. Wniosek ten potwierdzają również wyniki badań ankietowych przeprowadzonych w dwóch gminach wiejskich. Większość respondentów (oprócz mieszkańców gminy Kobylanka o zwiększonym dochodzie rozporządzalnym) uważa, że nie ma wolnych środków finansowych na pełne korzystanie ze wszystkich dostępnych usług. Obecnie większość rolników przeznacza 25-40\% swojego dochodu tylko na usługi i nie widzi możliwości, aby były to kwoty wyższe. W takich okolicznościach następne wyniki badań były zaskakujące, bowiem respondenci, którzy zaznaczyli chęć rozwijania działalności usługowej, chcą to czynić, opierając się przede wszystkim na kapitale własnym. Tylko co piąty badany zdecydowany jest na zaciągnięcie kredytu na nową działalność.

Rolnicy najczęściej korzystają z usług nieodpłatnych, np. edukacji, ochrony zdrowia i opieki społecznej oraz z takich usług, które są niezbędne do codziennego funkcjonowania, np. z usług komunalnych, informatycznych, transportowych i łączności, handlu i napraw oraz usług związanych ze sportem, z kulturą i rekreacją. Niestety zankietowani mieszkańcy wsi nie widzą możliwości rozwoju usług w swoim najbliższym otoczeniu. W związku z tym można założyć, że nowe usługi i nowe miejsca pracy zostaną utworzone nie na terenach wiejskich, ale w najbliższych miastach i miasteczkach. W ocenie ankietowanych na terenach przez nich zamieszkanych mogą ewentualnie rozwijać się agroturystyka, usługi powiązane ze sportem, z kulturą i rekreacją oraz transport.

Wniosek z przeprowadzonych badań jest taki, że bez względu na położenie gminy wiejskiej i poziom dochodów rolników ją zamieszkujących ankietowani nie widzą perspektyw na 
dynamiczny rozwój usług na terenach wiejskich. W związku z tym nie oczekują również, że powstaną nowe miejsca pracy związane $z$ usługami na terenach wiejskich. Wręcz odwrotnie: rolnicy chcą korzystać z większej gamy usług, ale zlokalizowanych w miastach i miasteczkach. Takie usługi utożsamiają oni z usługami cechującymi się wyższą jakością.

\section{PISMIENNICTWO}

Adamowicz M., Zwolińska-Ligaj M. 2009. Koncepcja wielofunkcyjności jako element zrównoważonego rozwoju obszarów wiejskich. PEFIM 51, 11-38.

Baza Danych Lokalnych, https://bdl.stat.gov.pl/BDL/start, dostęp: 20.01.2018.

FADN Public Database. Baza danych rachunkowości rolnej Komisji Europejskiej Departamentu RoInictwa i Rozwoju Obszarów Wiejskich, http://ec.europa.eu/agriculture/rica/database/report_ _en. cfm?dwh=SO, dostęp: 12.02.2018.

Ile zarabia polski rolnik? http://superbiz.se.pl/wiadomosci-biz/ile-zarabia-polski-rolnik-prawda-o-pieniadzach-na-wsi_593362.html, dostęp: 12.02.2018.

Kłodziński M. 2002. Perspektywy wielofunkcyjnego rozwoju gmin wiejskich w Polsce, w: Wieś i rolnictwo. Perspektywy rozwoju. Warszawa, IERiG, IRWiR PAN, 49-65.

Rocznik Statystyczny Polski. 2017. Warszawa, GUS.

Rocznik Statystyczny Województwa Zachodniopomorskiego. 2016. Warszawa, GUS.

Spychalski G. 2004. Wielofunkcyjność jako czynnik rozwoju obszarów wiejskich. Pr. Nauk. KPAiM SGGW 33, 44-47.

Statystyczne vademecum samorządowca 2017. Karnice, http://szczecin.stat.gov.pl/vademecum//vademecum_zachodniopomorskie/portrety_gmin/powiat_gryficki/gmina_wiejska_karnice.pdf, dostęp: 3.02.2018.

Statystyczne vademecum samorządowca 2017. Kobylanka, http://szczecin.stat.gov.pl/vademecum/ vademecum_zachodniopomorskie/portrety_gmin/powiat_stargardzki/gmina_wiejska_kobylanka.pdf, dostęp: 3.02.2018.

Woś A. 1998. Polityka wielofunkcyjnego rozwoju obszarów wiejskich, w: Identyfikacja priorytetów w modernizacji sektora rolno-żywnościowego w Polsce. Warszawa, FAPA, 43-45.

Streszczenie. W pracy starano się sprawdzić, czy polscy rolnicy dysponują odpowiednim dochodem i kapitałem własnym, który pozwala, $z$ jednej strony, na tworzenie nowych pozarolniczych miejsc pracy, a z drugiej strony umożliwia korzystanie $z$ usług oferowanych przez inne podmioty zlokalizowane na terenach wiejskich. Realizując cel pracy, w 2017 roku przeprowadzono również badania ankietowe w dwóch gminach w województwie zachodniopomorskim. Wyniki ankietowe miały pomóc w określeniu, z jakich usług rolnicy najczęściej korzystają i jaką część budżetu przeznaczają na usługi świadczone na terenach wiejskich. 
